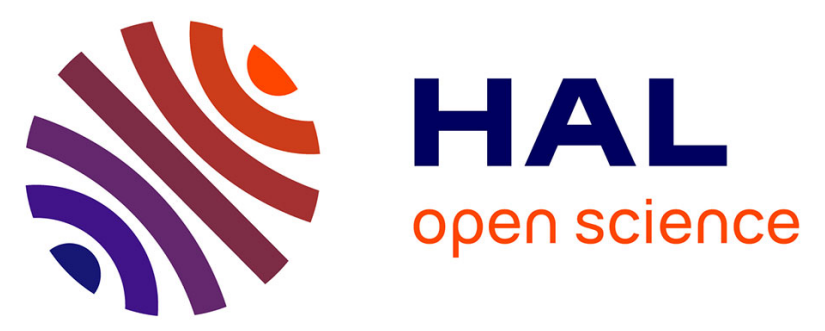

\title{
One-Pot Synthesis of Dihydropyrimidinones/Thiones Catalyzed by White Marble a Metamorphic Rock an Efficient and Reusable Catalyst for the Biginelli Reaction
}

\author{
K. El Mejdoubi, B. Sallek, H. Cherkaoui, H. Chaair, H. Oudadesse
}

\section{To cite this version:}

K. El Mejdoubi, B. Sallek, H. Cherkaoui, H. Chaair, H. Oudadesse. One-Pot Synthesis of Dihydropyrimidinones/Thiones Catalyzed by White Marble a Metamorphic Rock an Efficient and Reusable Catalyst for the Biginelli Reaction. Kinetics and Catalysis, 2018, 59 (3), pp.290-295. 10.1134/S0023158418030126 . hal-01833234

HAL Id: hal-01833234

https://hal-univ-rennes1.archives-ouvertes.fr/hal-01833234

Submitted on 10 Sep 2018

HAL is a multi-disciplinary open access archive for the deposit and dissemination of scientific research documents, whether they are published or not. The documents may come from teaching and research institutions in France or abroad, or from public or private research centers.
L'archive ouverte pluridisciplinaire HAL, est destinée au dépôt et à la diffusion de documents scientifiques de niveau recherche, publiés ou non, émanant des établissements d'enseignement et de recherche français ou étrangers, des laboratoires publics ou privés. 


\title{
One-Pot Synthesis of Dihydropyrimidinones/Thiones Catalyzed by White Marble a Metamorphic Rock: an Efficient and Reusable Catalyst for the Biginelli Reaction ${ }^{1}$
}

\author{
K. El Mejdoubi ${ }^{a, *}$, B. Sallek ${ }^{a, * *}$, H. Cherkaoui ${ }^{a}$, H. Chaair ${ }^{b}$, and H. Oudadesse ${ }^{c}$ \\ ${ }^{a}$ Laboratory of Agroressources, Polymers and Process Engineering, Faculty of Sciences, \\ Ibn Tofaïl University, Kenitra, 14000 Morocco \\ ${ }^{b}$ Laboratory of Processes Engineering, Faculty of Science and Techniques Mohammedia, Mohammedia, Morocco \\ ${ }^{c}$ Institute of Chemical Sciences of Rennes UMR CNRS 6226, University of Rennes, 1, France \\ *e-mail: elmejdoubi1989@gmail.com \\ **e-mail: brahimsallek@gmail.com
}

\begin{abstract}
In this work, we report a simple, efficient and green protocol for the synthesis of dihydropyrimidinones/thiones (products of Biginelli reaction) by the use of white marble as an effective heterogeneous catalyst. Short reaction times, high product yields, simple processing procedure and reusability of the catalyst are the superior characteristics of this protocol.
\end{abstract}

Keywords: Biginelli reaction, 3,4-dihydropyrimidin-2(1H)-ones/thiones, white marble, green catalyst

\section{INTRODUCTION}

In the concept of green chemistry, which is linked to a desire of scientists to take preventive and sustainable action on the environment, research has been developed for the application of new heterogeneous natural catalysts [1, 2], in the synthesis of therapeutic chemicals or key intermediates in the manufacturing of pharmaceutical chemicals.

The dihydropyrimidinone derivatives known as "Biginelli compounds" constitute an important class of compounds exhibiting broad range of pharmacological and biological activities such as inhibitors of the calcic channels, antihypertensive agents, antioxidants, anti-tumor activity, anti-cancer and antiinflammatory drugs [3-6]. The Biginelli reaction reported by the chemist P. Biginelli in 1893 involves the condensation of three components: a $\beta$-ketoester (ethyl acetoacetate) with an aldehyde and urea (or thiourea) under strongly acidic conditions [7]. This method of synthesis suffers however from disadvantages such as low yields in the case of certain substituted aliphatic and aromatic aldehydes with a long reaction time.

\footnotetext{
${ }^{1}$ The article is published in the original.
}

Recently, several synthetic methods for the preparation of dihydropyrimidinones to improve the efficiency of this reaction have been reported. These catalytic systems involve $\mathrm{Mn}(\mathrm{OAc})_{3} \cdot 2 \mathrm{H}_{2} \mathrm{O}$ [8], trifluoroacetic acid [9], boric acid [10], $\mathrm{CeCl}_{3} \cdot 7 \mathrm{H}_{2} \mathrm{O}$ [11], copper(II) triflate [12], $\mathrm{LiBr}$ [13], silica/sulfuric acid [14], zinc triflate [15], $\mathrm{I}_{2}$ [16], bismuth triflate [17], $\mathrm{LiClO}_{4}$ [18], $\mathrm{NH}_{4} \mathrm{Cl}$ [19], $\mathrm{ZrCl}_{4}$ [20], $\mathrm{Fe}(\mathrm{OTs})_{3} \cdot 6 \mathrm{H}_{2} \mathrm{O}$ [21], $\mathrm{Yb}(\mathrm{OTf})_{3}$ [22], benzyltriethylammonium chloride [23], $\mathrm{AlCl}_{3}: \mathrm{ZnCl}_{2}$ (3:1) [24], etidronic acid [25].

However, most of these methods suffer from one disadvantage or another, such as the use of dangerous and carcinogenic solvents, high catalyst loading or not recoverable catalysts that sometimes contain toxic metals. Therefore, there is a great need for new catalytic processes which do not have these problems.

In this paper we would like to point out our work on white marble (WM) to catalyze the synthesis reaction of dihydropyrimidinones with great efficiency and excellent reusability. The catalyst can be easily recovered and still retains its catalytic activity.

We have shown that white marble could be considered as a new heterogeneous catalyst for the Biginelli reaction. 
Transmittance, $\%$

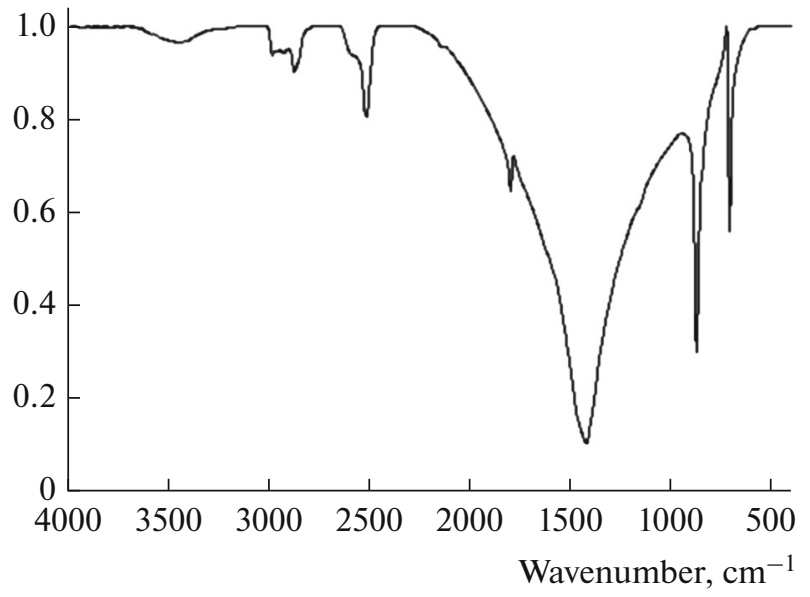

Fig. 1. FT-IR spectrum of marble powder.

\section{MATERIALS AND METHODS}

Characterization of the Catalyst: Marble Powder

The marble powder used as a basic precursor in the preparation of catalysts is the waste from the marble works due to the cutting of white marble pieces. A sample was subjected to a treatment consisting of washing with water and ethanol followed by preliminary sieving to remove the impurities. After this operation, the grinding is carried out with sieving which makes it possible to retain the granulometry of the carbonate at a size between 63 and $125 \mu \mathrm{m}$. The carbonate thus obtained is dried and preserved at $100^{\circ} \mathrm{C}$ in the oven.

The recovered after treatment powder have been characterized by Fourier transform infrared spectroscopy (FT-IR), X-ray diffraction (XRD), the elemental analysis by energy dispersion spectroscopy (EDS) using a fluorescence $\mathrm{X}$ spectrometer and by measuring the specific surface.

Table 1. Mineralogical composition of marble powder

\begin{tabular}{l|c}
\hline Compound & Concentration, \% \\
\hline $\mathrm{CaO}$ & 78 \\
$\mathrm{P}_{2} \mathrm{O}_{5}$ & 0.156 \\
$\mathrm{~F}$ & 3.08 \\
$\mathrm{SiO}_{2}$ & 0.397 \\
$\mathrm{SO}_{3}$ & 0.143 \\
$\mathrm{Na}_{2} \mathrm{O}$ & 0.0874 \\
$\mathrm{Al}_{2} \mathrm{O}_{3}$ & 0.195 \\
$\mathrm{MgO}$ & 1.11 \\
$\mathrm{Fe}_{2} \mathrm{O}_{3}$ & 0.0723 \\
\hline
\end{tabular}

Intenisity, count

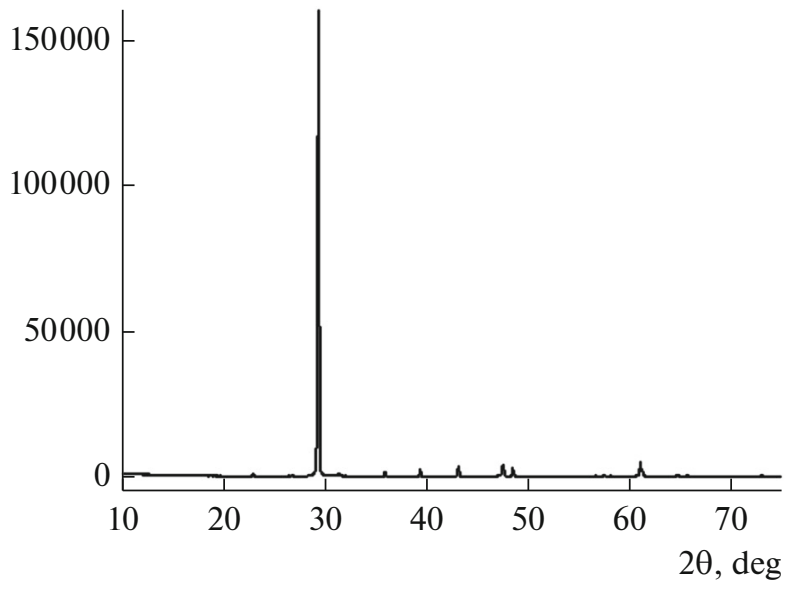

Fig. 2. XRD pattern of marble powder.

FT-IR reveals several bands, in particular those attributable to carbonate ions $\mathrm{CO}_{3}^{2-}$ (Fig. 1). We have thus identified the adsorption bands characteristic of carbonates at 1480,870 and $713 \mathrm{~cm}^{-1}$. Analysis of the X-ray powder diffraction pattern (Fig. 2) showed a well-crystallized phase. The presence of calcite was confirmed by the characteristic 104 and 113 reflections at $29.41^{\circ}$ and $39.39^{\circ}$ (20) (Joint Committee on Powder Diffraction International Centre for Diffraction Data Further (JCPDS: 86-2334). Note the absence of the characteristic reflections of calcium carbonate in the different allotropes aragonite (JCPDS: 76-0606) and vaterite (JCPDS: 74-1867) [26-30].

The elemental analysis of the main constituent elements of the same samples was determined by EDS. Table 1 gives the mineralogical composition of the powder of marble used in this study. The powder of marble has an average specific surface area of $4.23 \mathrm{~m}^{2} / \mathrm{g}$ as measured by the BET method.

\section{General Procedure for the Synthesis of Dihydropyrimidinones/Thiones}

In a conventional procedure, ethyl acetoacetate $(1 \mathrm{mmol})$, aldehyde $(1 \mathrm{mmol})$ and urea or thiourea $(1.5 \mathrm{mmol})$ were mixed with WM as a catalyst (10 $\mathrm{mol} \%$, $0.01 \mathrm{~g}$ ) and heated to reflux in the presence of ethanol $(3 \mathrm{~mL})$ as a solvent for an appropriate time. The progress of the reaction was monitored by TLC. After completion of the reaction, the catalyst was recovered by filtration. The filtrate was evaporated and the crude product purified by recrystallization from ethanol to give the pure product. The products were identified by comparison with melting points of the authentic compounds, and by ${ }^{1} \mathrm{H}$ and ${ }^{13} \mathrm{C}$ NMR. 
Table 2. Effect of WM mass on condensation reaction of $\mathbf{1 a}$, 2 and $3 *$

\begin{tabular}{c|c|c|c}
\hline Entry & $\begin{array}{c}\text { Catalyst, } \\
\text { mol \% }\end{array}$ & Time, min & Yield, \%** \\
\hline 1 & - & 480 & No reaction \\
2 & 10 & 45 & 93 \\
3 & 20 & 45 & 86 \\
4 & 30 & 45 & 80 \\
5 & 40 & 45 & 72 \\
6 & 50 & 45 & 65 \\
7 & 100 & 45 & 48 \\
\hline
\end{tabular}

* Reaction conditions: 1a (1 mmol), 2 (1 mmol), 3 (1.5 mmol), catalyst, EtOH $(3 \mathrm{~mL}), 80^{\circ} \mathrm{C}$, for $45 \mathrm{~min}$.

** Isolated yield.

\section{Spectral Data of Typical Compounds}

5-(Ethoxycarbonyl)-6-methyl-4-phenyl-3,4-dihydropyrimidin-2(1H)-one (4a). ${ }^{1} \mathrm{H}$ NMR $(300 \mathrm{MHz}$, DMSO-d $\left.{ }_{6}\right), \delta$, ppm: $9.17(\mathrm{~s}, 1 \mathrm{H}, \mathrm{NH}), 7.73(\mathrm{~s}, 1 \mathrm{H}$, $\mathrm{NH}), 7.21-7.33(\mathrm{~m}, 5 \mathrm{H}, \mathrm{ArH}), 5.14(\mathrm{~d}, 1 \mathrm{H}, \mathrm{CH}), 4.00$ $\left(\mathrm{q}, 2 \mathrm{H}, \mathrm{OCH}_{2}\right), 2.23\left(\mathrm{~s}, 3 \mathrm{H}, \mathrm{CH}_{3}\right), 1.09(\mathrm{t}, 3 \mathrm{H}$, $\left.\mathrm{OCH}_{2} \mathrm{CH}_{3}\right) \cdot{ }^{13} \mathrm{C}$ NMR (300 MHz, DMSO-d 6 ), $\delta$, ppm: 165.80, 152.62, 148.81, 145.33, 128.85, 127.72, $126.71,99.74,59.65,54.44,18.24,14.53$.

5-(Ethoxycarbonyl)-4-(4-chlorophenyl)-6-methyl3,4-dihydropyrimidin-2(1H)-one (4b). ${ }^{1} \mathrm{H} \quad \mathrm{NMR}$ $\left(300 \mathrm{MHz}, \mathrm{DMSO}-\mathrm{d}_{6}\right), \delta$, ppm: $9.22(\mathrm{~s}, 1 \mathrm{H}, \mathrm{NH})$, $7.76(\mathrm{~s}, 1 \mathrm{H}, \mathrm{NH}), 7.21-7.38(\mathrm{~m}, 4 \mathrm{H}, \mathrm{ArH}), 5.13(\mathrm{~d}$, $1 \mathrm{H}, \mathrm{CH}), 3.99\left(\mathrm{q}, 2 \mathrm{H}, \mathrm{OCH}_{2}\right), 2.23\left(\mathrm{~s}, 3 \mathrm{H}, \mathrm{CH}_{3}\right), 1.09$ (t, $\left.3 \mathrm{H}, \mathrm{OCH}_{2} \mathrm{CH}_{3}\right),{ }^{13} \mathrm{C}$ NMR $(300 \mathrm{MHz}, \mathrm{DMSO}-$ $\mathrm{d}_{6}$ ), $\delta$, ppm: 165.67, 152.41, 149.19, 144.25, 132.25, $128.86,128.65,99.30,59.72,53.88,18.26,14.53$.

5-(Ethoxycarbonyl)-6-methyl-4-(p-tolyl)-3,4-dihydropyrimidin-2(1H)-one (4c). ${ }^{1} \mathrm{H}$ NMR $(300 \mathrm{MHz}$, DMSO-d $\left.{ }_{6}\right), \delta$, ppm: $9.13(\mathrm{~s}, 1 \mathrm{H}, \mathrm{NH}), 9.12(\mathrm{~s}, 1 \mathrm{H}$, $\mathrm{NH}), 7.65-7.67$ (m, 4H, ArH), $5.09(\mathrm{~d}, 1 \mathrm{H}, \mathrm{CH})$, $3.99\left(\mathrm{q}, 2 \mathrm{H}, \mathrm{OCH}_{2}\right), 3.31\left(\mathrm{~s}, 3 \mathrm{H}, \mathrm{CH}_{3}\right), 2.21(\mathrm{~s}, 3 \mathrm{H}$, $\left.\mathrm{CH}_{3}\right), 1.09\left(\mathrm{t}, 3 \mathrm{H}, \mathrm{OCH}_{2} \mathrm{CH}_{3}\right) \cdot{ }^{13} \mathrm{C} \mathrm{NMR}(300 \mathrm{MHz}$, DMSO-d $\left.{ }_{6}\right), \delta$, ppm: 165.82, 152.63, 148.61, 142.42, $136.82,129.35,126.61,99.88,59.62,54.09,21.11$, $18.22,14.56$.
5-(Ethoxycarbonyl)-4-(4-nitrophenyl)-6-methyl3,4-dihydropyrimidin-2(1H)-one (4d). ${ }^{1} \mathrm{H} \quad \mathrm{NMR}$ $\left(300 \mathrm{MHz}, \mathrm{DMSO}-\mathrm{d}_{6}\right), \delta$, ppm: $9.32(\mathrm{~s}, 1 \mathrm{H}, \mathrm{NH})$, 8.18-8.21 (d, 2H, ArH), 7.87 (s, 1H, NH), 7.47-7.50 $(\mathrm{d}, 2 \mathrm{H}, \mathrm{ArH}), 5.26(\mathrm{~d}, 1 \mathrm{H}, \mathrm{CH}), 4.00\left(\mathrm{q}, 2 \mathrm{H}, \mathrm{OCH}_{2}\right)$, $2.25\left(\mathrm{~s}, 3 \mathrm{H}, \mathrm{CH}_{3}\right), 1.09\left(\mathrm{t}, 3 \mathrm{H}, \mathrm{OCH}_{2} \mathrm{CH}_{3}\right) \cdot{ }^{13} \mathrm{C} \mathrm{NMR}$ (300 MHz, DMSO-d $\mathrm{d}_{6}$ ), $\delta$, ppm: $165.52,152.46$, $152.21,149.86,147.18,128.12,124.30,98.64,59.86$, $54.15,18.33,14.51$.

5-(Ethoxycarbonyl)-6-methyl-4-phenyl-3,4-dihydropyrimidin-2(1H)-thione (4e). ${ }^{1} \mathrm{H}$ NMR $(300 \mathrm{MHz}$, DMSO-d $\left.{ }_{6}\right), \delta$ ppm: $10.31(\mathrm{~s}, 1 \mathrm{H}, \mathrm{NH}), 9.64(\mathrm{~s}, 1 \mathrm{H}$, NH), 7.19-7.35 (m, 5H, ArH), $5.17(\mathrm{~d}, 1 \mathrm{H}, \mathrm{CH}), 4.02$ $\left(\mathrm{q}, 2 \mathrm{H}, \mathrm{OCH}_{2}\right), 2.28\left(\mathrm{~s}, 3 \mathrm{H}, \mathrm{CH}_{3}\right), 1.10(\mathrm{t}, 3 \mathrm{H}$, $\left.\mathrm{OCH}_{2} \mathrm{CH}_{3}\right) .{ }^{13} \mathrm{C}$ NMR $\left(300 \mathrm{MHz}, \mathrm{DMSO}-\mathrm{d}_{6}\right), \delta$, ppm: 174.71, 165.59, 145.49, 143.96, 129.02, 128.14, $126.85,101.19,60.05,54.51,17.63,14.47$.

5-(Ethoxycarbonyl)-4-(4-methoxyphenyl)-6-methyl3,4-dihydropyrimidin-2(1H)-thione (4f). ${ }^{1} \mathrm{H}$ NMR (300 MHz, DMSO-d $)_{6}$, $\delta$, ppm: $10.27(\mathrm{~s}, 1 \mathrm{H}, \mathrm{NH})$, $9.58(\mathrm{~s}, 1 \mathrm{H}, \mathrm{NH}), 6.86-7.43(\mathrm{~m}, 4 \mathrm{H}, \mathrm{ArH}), 5.10$ (s, $1 \mathrm{H}, \mathrm{CH}), 4.01\left(\mathrm{q}, 2 \mathrm{H}, \mathrm{OCH}_{2}\right), 3.70\left(\mathrm{~s}, 3 \mathrm{H}, \mathrm{OCH}_{3}\right)$, $2.26\left(\mathrm{~s}, 3 \mathrm{H}, \mathrm{CH}_{3}\right), 1.11\left(\mathrm{t}, 3 \mathrm{H}, \mathrm{OCH}_{2} \mathrm{CH}_{3}\right) .{ }^{13} \mathrm{C} \mathrm{NMR}$ $\left(300 \mathrm{MHz}, \mathrm{DMSO}-\mathrm{d}_{6}\right), \delta$, ppm: 174.48, 165.63, 159.20, 145.21, 136.16, 128.08, 114.34, 101.42, 60.00, $55.56,53.90,17.60,14.49$.

\section{RESULTS AND DISCUSSION}

\section{Evaluation of the Catalytic Activity of WM in the Synthesis of Dihydropyrimidinones}

Initial studies were realized using the benzaldehyde (1 mmol), ethyl acetoacetate $(1 \mathrm{mmol})$ and urea $(1.5 \mathrm{mmol})$ as the model reaction (Scheme 1). The reaction was carried out in $\mathrm{EtOH}$ at $80^{\circ} \mathrm{C}$ with a different catalyst mass. The best yield $(93 \%)$ was obtained using $10 \mathrm{~mol} \%$ of the catalyst after $45 \mathrm{~min}$ (Table 2 ). In addition, the experiment was also carried out under identical reaction conditions without the catalyst, no trace of the product was found after $480 \mathrm{~min}$. It was evident that MW was the most effective catalyst among of the catalysts tested.

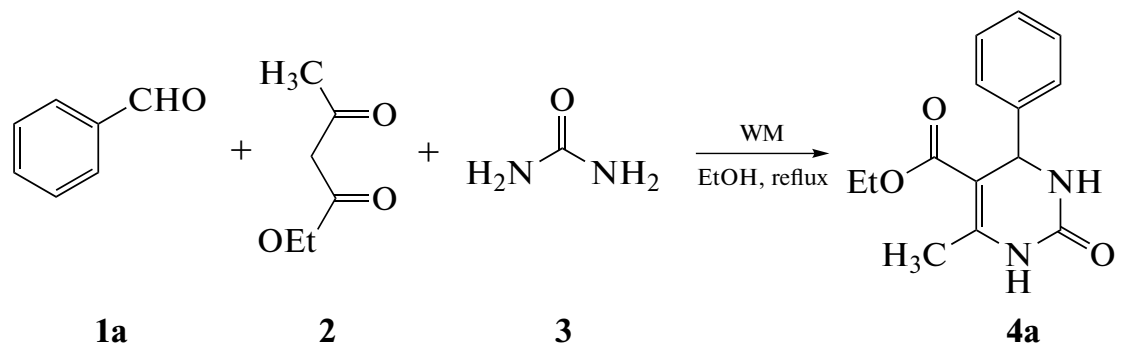

Scheme 1. The model reaction between benzaldehyde (1a), ethyl acetoacetate (2) and urea (3) in the presence of catalyst. 


\section{Effect of Solvents}

The effect of various solvents (such as $\mathrm{MeOH}$, EtOH, AcOEt, $\mathrm{CH}_{2} \mathrm{Cl}_{2}, \mathrm{CH}_{3} \mathrm{CN}$, THF, $\mathrm{CHCl}_{3}$, and 1,4-dioxane) on the model reaction was studied in the presence of WM (10 mol \%). The results indicate that the solvents had a significant effect on the yield of the product. The use of dioxane, AcOEt and $\mathrm{CHCl}_{3}$ as solvent resulted in low yields (Table 3, entries 5, 7 and 10). Solvents such as $\mathrm{H}_{2} \mathrm{O}, \mathrm{CH}_{3} \mathrm{CN}$, tetrahydrofuran (THF) and $\mathrm{CH}_{2} \mathrm{Cl}_{2}$ gave moderate yields (Table 3 , entries 4, 6, 8 and 9). The best conversion was observed when the reaction was carried out in ethanol (Table 3, entry 2). On the basis of these results, EtOH was then selected as a solvent for other investigations.

\section{Time Effect of the Reaction}

To study the effect of the reaction time (Table 4), the catalyst mass of $0.01 \mathrm{~g}(10 \mathrm{~mol} \%)$ was chosen as the optimum mass in the presence of $\mathrm{EtOH}$ as solvent. The reaction mixture at $80^{\circ} \mathrm{C}$ for a short reaction time (45 min) gave $93 \%$ of 4 a (Table 4 , entry 6 ). However, when the reaction time was increased, the yield of the 4a started to decrease.

\section{Study of the Reusability of the Catalyst}

To accomplish this study, we examined the reuse of the catalyst. Indeed, a heterogeneous catalyst is not considered interesting in organic synthesis if it can be easily recovered and reused.

After completion of the reaction between benzaldehyde, ethyl acetoacetate and urea, the catalyst was recovered by simple filtration and then washed with water and ethanol $(2 \times 5 \mathrm{~mL})$ to remove any trace of reagents and final products adsorbed on the catalyst, then dried in an oven at $80^{\circ} \mathrm{C}$. The catalyst was reused directly in the model reaction without any additional treatments. The efficiency of the recovered catalyst was measured again by using the same reaction model. As shown in Table 5, the reaction yield reached $>80 \%$ after 5 cycles. To the best of our knowledge, the reuse of this catalyst is significantly better than that for most supported catalysts reported.

\section{Generalization}

Using the optimum conditions, we have extended this study with various aldehydes, ethyl acetoacetate and urea or thiourea for the synthesis of a variety of 3,4-dihydropyrimidin-2 $(1 \mathrm{H})$-one derivatives/thiones (Scheme 2). The relevant data are presented in Table 6 . The reactions gave the desired products with satisfactory yields (8896\%) depending on the substrate and the conditions used for the reaction (Table 6, entries 1-6).
Table 3. Effect of different solvents on the synthesis of dihydropyrimidinone (4a) catalyzed by WM*

\begin{tabular}{|c|c|c|c|}
\hline Entry & Solvent & Time, $\min$ & Yield, \%** \\
\hline 1 & No solvent & 60 & 66 \\
\hline 2 & EtOH & 45 & 93 \\
\hline 3 & $\mathrm{MeOH}$ & 45 & 81 \\
\hline 4 & $\mathrm{H}_{2} \mathrm{O}$ & 45 & 68 \\
\hline 5 & Dioxane & 45 & 49 \\
\hline 6 & $\mathrm{CH}_{3} \mathrm{CN}$ & 45 & 64 \\
\hline 7 & AcOEt & 45 & 52 \\
\hline 8 & THF & 45 & 73 \\
\hline 9 & $\mathrm{CH}_{2} \mathrm{Cl}_{2}$ & 45 & 69 \\
\hline 10 & $\mathrm{CHCl}_{3}$ & 45 & 41 \\
\hline
\end{tabular}

* Reaction conditions: 1a $(1 \mathrm{mmol}), 2$ (1 mmol), 3 (1.5 mmol), catalyst $(10 \mathrm{~mol} \%)$, EtOH $(3 \mathrm{~mL}), 80^{\circ} \mathrm{C}$, for $45 \mathrm{~min}$.

** Isolated yield.

Table 4. Effect of reaction time on the yield of dihydropyrimidinone (4a) in the presence of $\mathrm{WM}^{*}$

\begin{tabular}{c|c|c}
\hline Entry & Time, min & Yield, \%** \\
\hline 1 & 3 & 12 \\
2 & 5 & 23 \\
3 & 10 & 57 \\
4 & 15 & 68 \\
5 & 30 & 86 \\
6 & 45 & 93 \\
7 & 60 & 81 \\
8 & 120 & 75 \\
\hline
\end{tabular}

* Reaction conditions: 1a (1 mmol), 2 (1 mmol), 3 (1.5 mmol), catalyst, EtOH $(3 \mathrm{~mL}), 80^{\circ} \mathrm{C}$, for specified time.

** Isolated yield.

Table 5. Reusability of WM in the synthesis of 3,4-dihydropyrimidinones*

\begin{tabular}{c|c|c|c}
\hline Entry & $\begin{array}{c}\text { Number } \\
\text { of recycling } \\
\text { runs }\end{array}$ & Time, min & Yield, \%** \\
\hline 1 & 1 & 45 & 93 \\
2 & 2 & 45 & 93 \\
3 & 3 & 45 & 91 \\
4 & 4 & 45 & 89 \\
5 & 5 & 45 & 86 \\
\hline
\end{tabular}

* Reaction conditions: 1a $(1 \mathrm{mmol}), \mathbf{2 a}(1 \mathrm{mmol})$ and $3 \mathbf{a}$ $(1.5 \mathrm{mmol})$, catalyst $(0.01 \mathrm{~g})$, EtOH $(3 \mathrm{~mL}), 80^{\circ} \mathrm{C}$, for $45 \mathrm{~min}$. ** Isolated yield. 
<smiles>[R]c1ccc(C=O)cc1</smiles>

Scheme 2. Generalization of the synthesis of dihydropyrimidinones/thiones.

\section{Comparison of the Catalytic Activity of WM and Other Catalysts}

To establish the catalytic activity of the WM, we compared the results obtained on the synthesis of 3,4- dihydropyrimidinones with the literature data (Table 7). Based on this comparison, we see that the used catalyst (WM) presents higher yields and shorter reaction time compared to other reported systems [34-41].

Table 6. Synthesis of dihydropyrimidinones/thiones from various aromatic aldehydes with ethyl acetoacetate and urea or thiourea catalyzed by WM

\begin{tabular}{|c|c|c|c|c|c|c|c|}
\hline \multirow{2}{*}{ Entry } & \multirow{2}{*}{ Product } & \multirow{2}{*}{$\mathrm{R}$} & \multirow{2}{*}{$\mathrm{X}$} & \multirow{2}{*}{ Time, $\min$} & \multirow{2}{*}{ Yield, \%* } & \multicolumn{2}{|c|}{ M.p., ${ }^{\circ} \mathrm{C}$} \\
\hline & & & & & & found & reported \\
\hline 1 & $4 a$ & $\mathrm{H}$ & $\mathrm{O}$ & 45 & 93 & $204-206$ & $207-208$ [31] \\
\hline 2 & $4 \mathrm{~b}$ & $4-\mathrm{Cl}$ & $\mathrm{O}$ & 35 & 89 & $210-212$ & $212-214[32]$ \\
\hline 3 & $4 c$ & $4-\mathrm{Me}$ & $\mathrm{O}$ & 55 & 90 & $214-218$ & $216-218[32]$ \\
\hline 4 & $4 d$ & $4-\mathrm{NO}_{2}$ & $\mathrm{O}$ & 50 & 96 & $210-214$ & $211-212[32]$ \\
\hline 5 & $4 e$ & $\mathrm{H}$ & S & 40 & 88 & $208-210$ & $206-208[31]$ \\
\hline 6 & $4 f$ & 4-MeO & S & 25 & 91 & $150-154$ & 153 [33] \\
\hline
\end{tabular}

* Isolated yield.

Table 7. Comparison of the efficiency of WM with certain catalysts reported in the literature

\begin{tabular}{|c|c|c|c|c|c|c|}
\hline Entry & Catalyst & Reaction conditions & $\begin{array}{c}\text { Number } \\
\text { of recycling } \\
\text { runs }\end{array}$ & $\begin{array}{l}\text { Reaction } \\
\text { time, } \mathrm{h}\end{array}$ & Yield, \% & Reference \\
\hline 1 & WM (10\%) & Ethanol $/ 100^{\circ} \mathrm{C}$ & $5(93-86 \%)$ & 0.75 & 93 & This study \\
\hline 2 & PS-PEG-SO ${ }_{3} \mathrm{H}(0.3 \mathrm{~g})$ & Dioxane/2-propanol $/ 80^{\circ} \mathrm{C}$ & Not studied & 10 & 80 & [34] \\
\hline 3 & Montmorillonite KSF (15\%) & $\mathrm{H}_{2} \mathrm{O} / 100^{\circ} \mathrm{C}$ & Not studied & 48 & 78 & [35] \\
\hline 4 & Silica-sulfuric acid (35\%) & Ethanol/reflux & Not studied & 6 & 91 & [14] \\
\hline 5 & $\begin{array}{l}\text { Molybdophosphoric acid } \\
(2 \%)\end{array}$ & $\mathrm{AcOH} /$ reflux & $6(94-85 \%)$ & 4 & 70 & [36] \\
\hline 6 & $\begin{array}{l}\mathrm{Fe}_{3} \mathrm{O}_{4} @ \text { Silica sulfuric acid } \\
(0.05 \mathrm{~g})\end{array}$ & No solvent $/ 80^{\circ} \mathrm{C}$ & $4(92-81 \%)$ & 0.6 & 92 & [37] \\
\hline 7 & $\begin{array}{l}\text { Triphenylphosphine (PPh3) } \\
(10 \mathrm{~mol} \%)\end{array}$ & No solvent $/ 100^{\circ} \mathrm{C}$ & Not studied & 10 & 70 & [38] \\
\hline 8 & $\begin{array}{l}\mathrm{Fe}_{3} \mathrm{O}_{4} @ \text { mesoporous SBA-15 } \\
(50 \mathrm{mg})\end{array}$ & Ethanol/r.t. & $7(85-70 \%)$ & 6 & 85 & [39] \\
\hline 9 & $\mathrm{SiO}_{2}-\mathrm{Cl}(2.5 \mathrm{~mol} \%)$ & No solvent $/ 80^{\circ} \mathrm{C}$ & Not studied & 3 & 88 & [40] \\
\hline 10 & ASA NPs (10 mol \%) & No solvent $/ 70^{\circ} \mathrm{C}$ & $6(94-60 \%)$ & 5.3 & 94 & [41] \\
\hline
\end{tabular}




\section{CONCLUSIONS}

In conclusion, we used the white marble as a new heterogeneous and effective catalyst in the reaction of Biginelli for the synthesis of 3,4-dihydropyrimidin-2$(1 \mathrm{H})$-ones and their analogues (thiones) by cyclocondensation of aldehydes, urea/thiouria and ethyl acetoacetate in ethanol. The WM showed a high reactivity with $82-96 \%$ conversion in $15-45 \mathrm{~min}$ at reflux for the various dihydropyrimidinone/thiones in $3 \mathrm{~mL}$ of ethanol. In addition, this method offers several advantages, including mild reaction conditions, low catalyst loading, short reaction times, and high yields. The catalyst can be recovered and reused up to 6 times without significant loss of activity.

\section{REFERENCES}

1. Benzekri, Z., Serrar, H., Boukhris, S., Sallek, B., and Souizi, A., Curr. Chem. Lett., 2016, vol. 5, p. 99.

2. El Mejdoubi, K., Bahammou, R., Benzekri, Z., Sallek, B., Cherkaoui, H., and Boukhris, S., Int. J. Sci. Eng. Res., 2017, vol. 8, N 1, p. 419.

3. Lal, J., Gupta, S.K., Thavaselvam, D., and Agarwal, D.D., Med. Chem. Lett., 2012, vol. 22, p. 2872.

4. Wan, J.P., Mini.-Rev. Med. Chem., 2012, vol. 12, p. 337.

5. Wan, J.P. and Liu, Y., Synthesis, 2010, vol. 23, p. 3943.

6. Narahari, S.R., Reguri, B.R., Gudaparthi, O., and Mukkanti, K., Tetrahedron Lett., 2012, vol. 53, p. 1543.

7. Biginelli, P., Gazz. Chim. Ital., 1893, vol. 23, p. 360.

8. Kumar, K.A., Kasthuraiah, M., Reddy, C.S., and Reddy, C.D., Tetrahedron Lett., 2001, vol. 42, p. 7873.

9. Bussolari, J.C. and McDonnel, P.A., J. Org. Chem., 2000, vol. 65, p. 6777.

10. Tu, S., Fang, F., Miao, C., Jiang, H., Feng, Y., Shi, D., and Wang, X., Tetrahedron Lett., 2003, vol. 44, p. 6153.

11. Bose, D.S., Fatima, L., Miao, C., Jiang, H., Feng, Y., Shi, D., and Wang, X.J., Org. Chem., 2003, vol. 68, p. 587.

12. Paraskar, A.S., Dewkar, G.K., and Sudalai, A., Tetrahedron Lett., 2003, vol. 44, p. 3305.

13. Maiti, G., Kundu, P., and Guin, C., Tetrahedron Lett., 2003, vol. 44, p. 2757.

14. Salehi, P., Dabiri, M., Zolfigol, M.A., and Bodaghi Fard, M.A., Tetrahedron Lett., 2003, vol. 44, p. 2889.

15. Xu, H. and Wang, Y., Chin. J. Chem., 2003, vol. 21, p. 327.

16. Srinivas, K.V.N. and Das, B., Synthesis, 2004, vol. 13, p. 2091.

17. Varala, R., Alam, M.M., and Adapa, S.R., Synlett, 2003, vol. 1, p. 67.

18. Yadav, J.S., Reddy, B.V.S., Srinivas, R., Venugopal, C., and Ramalingam, T., Synthesis, 2001, vol. 9, p. 1341.
19. Shaabani, A., Bazgir, A., and Teimouri, F., Tetrahedron Lett., 2003, vol. 44, p. 857.

20. Reddy, C.V., Mahesh, M., Raju, P.V.K., Babu, T.R., and Reddy, V.V.N., Tetrahedron Lett., 2002, vol. 43, p. 2657.

21. Starcevich, J.T., Laughlin, J.T., and Mohan, R.S., Tetrahedron Lett., 2013, vol. 54, p. 983.

22. Kang, S., Coopera, G., Dunned, S. F., Luand, C.H., Surmeier, J. D., and Silverman, R. B., Bioorg. Med. Chem., 2013, vol. 21, p. 4365.

23. Bose, D.S., Sudharshan, M., and Chavhan, S.W., ARKIVOC, 2005, vol. 3, p. 228.

24. Balalaie, S., Soleiman-Beigi, M., and Rominger, F.J., J. Iran. Chem. Soc., 2005, vol. 2, p. 319.

25. Pansuriya, A.M., Savant, M.M., Bhuva, C.V., Singh, J., and Naliapara, Y.T., ARKIVOC, 2009, vol. VII, p. 79.

26. Ren, M., Dong, Ch., and An, Ch., Materials, 2011, vol. 4, p. 1375.

27. Hu, Z. and Deng, Y., Powder Technol., 2004. vol. 140, p. 10.

28. Nurul Islam, Kh., Eaqub Ali, Md., Zuki Bin Abu Bakar, Md., Loqman, M.Y., Islam, A., Saiful Islam, Md., Mahfujur Rahman, Md., and Ullah, M., Powder Technol., 2013, vol. 246, p. 434.

29. Chen, J. and Xiang, L., Powder Technol., 2009, vol. 189, p. 64.

30. Ma, H.Y. and Lee, I.S., Mater. Sci. Eng., C, 2006, vol. 26, p. 721.

31. Mobinikhaledi, A., Foroughifar, N., and KhajehAmiri, A., React. Kinet. Mech. Catal., 2015, vol. 117, p. 59.

32. Zare, A. and Nasouri, Z., J. Mol. Liq., 2016, vol. 216, p. 364.

33. Javidi, J., Esmaeilpour, M., and Dodeji, F.N., RSC $A d v ., 2015$, vol. 5, N 1, p. 308.

34. Quan, Z.J., Da, Y.X., Zhang, Z., and Wang, X.C., Catal. Commun., 2009, vol. 10, p. 1146.

35. Bigi, F., Carloni, S., Frullanti, B., Maggi, R., and Sartori, G., Tetrahedron Lett., 1999, vol. 40, p. 3465.

36. Heravi, M.M., Bakhtiari, K., and Bamoharram, F.F., Catal. Commun., 2006, vol. 7, p. 376.

37. Ali Reza, K. and Davarpanah, J., Res. Chem. Intermed., 2015, vol. 41, no. 5, p. 2991.

38. Debache, A., Amimour, M., Belfaitah, A., Rhouati, S., and Carboni, B., Tetrahedron Lett., 2008, vol. 49, p. 6119 .

39. Mondal, J., Sen, T., and Bhaumik, A., Dalton Trans., 2012, vol. 41, p. 6173.

40. Karade, H.N., Sathe, M., and Kaushik, M.P., Mol., 2007, vol. 12, p. 1341.

41. Nasr-Esfahani, M. and Taei, M., RSC Adv., 2015, vol. 5, p. 44978. 